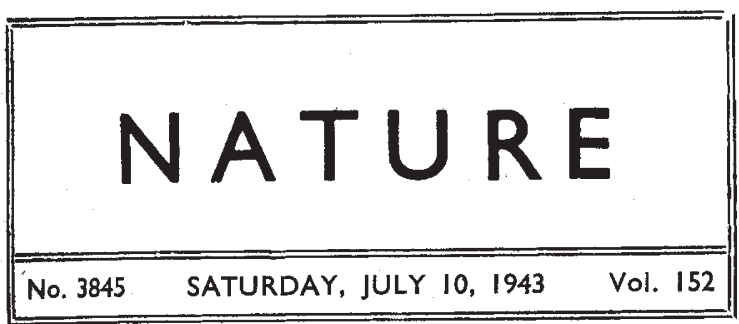

CONTENTS

Co-operation in Scientific Research in the British Empire

Impact of Social Influences upon Art. By F. Ian G. Rawlins

Copernicus

The Life-History of a Pueblo Indian. By Mrs. Rishbeth

Science in South-West China : II. The Biological and Social Sciences. By Dr. Joseph Needham, F.R.S. .

Structure of $a-$ Keratin. By Dr. Ian MacArthur .

The Island of New Guinea. By Miss L. Evelyn Cheesman

News and Views

Letters to the Editors :

Biological Research in the West Indies.-Dr. V. J. Chapman

Ribonucleic Acids in Animal Tissues.-Dr. J. N. Davidson and Miss C. Waymouth .

Inhibition of Urease Activity by Ascorbic Acid.L. A. Elson

Mechanism of Polysaccharide. Production from Sucrose.-Shlomo Hestrin and Mrs. S. AvineriShapiro

Pore Canals of the Insect Cuticle.-R. Dennell .

The Term Tractellum in Flagellate Organisms.A. G. Lowndes

How the Sperm Reaches the Archegonium in Pellia epiphylla.-Prof. John Walton

A New Method of Electrical Testing, Applied to Insulated Wires.-H. A. Macdonald and E. C. R. Scarfe .

Biological Control of the Fly Population in Sewage Filters.-T. G. Tomlinson

Treatment of Cancer by Fast Neutrons. By Dr. L. H. Gray and Dr. J. Read

Ultra-High Electromagnetic Frequencies

The Insects of Guam. By Dr. A. D. Imms, F.R.S.

Editorial and Publishing Offices

MACMILLAN \& CO., LTD.

ST. MARTIN'S STREET, LONDON, W.C.2.

Telephone Number: Whitehall 8831

Telegrams: Phusis Lesquare London

Advertisements should be addressed to

T. G. Scott \& Son, Ltd., Talbot House, 9 Arundel Street, London, W.C.2 Telephone: Temple Bar 1942

The annual subscription rate is $\mathrm{E} 4100$, payable in advance, Inland or Abroad. All rights reserved. Registered as a Newspaper at the General Post Office

\section{CO-OPERATION IN SCIENTIFIC RESEARCH IN THE BRITISH EMPIRE}

A FEATURE of the discussions at the conference on the Planning of Science arranged by the Association of Scientific Workers last January was the constant reference to the need for closer interAllied co-operation, and in particular to the need for extending the arrangements by which young workers from the war laboratories may visit their colleagues in other countries, not merely for discussion but also to work side by side in allied teams. The value of fostering contacts between workers in the universities, in industry, and in Government departments, and of frequent exchange of staff as well as of information, was clearly recognized, and was afterwards reiterated by Dr. P. Dunsheath in a paper before the Royal Society of Arts. Similarly, the importance of establishing a central information bureau from which such scientific and technical liaison could be conducted as to ensure that departmental missions are at least in 41. touch with one another, and that those at the centre know what all, and not just a few, of the various departments are doing, no longer appears to be in dispute.

Specific recommendations have now been made in a report of the British Commonwealth Science Committee set up under the chairmanship of the president the Royal Society in October 1941 as the outcome of a conference held at the Royal Society's rooms on October 7, 1941. This conference included representa. tives of the Dominions and.India, and of the Royel Society; and the secretaries of the Medical and Agricultural Research Councils and the secretary of the Department of Scientific and Industrial Research,

50 Lord Hankey and others were invited. The general objectives were to secure scientific co-operation in I tackling the emergency problems of the immediate post-war period and to ensure that the most should be made of our common scientific resources after the War for improving both scientific knowledge itself and the life of the peoples of the Empire; in par-

51. ticular, the conference was to consider means of promoting co-operation between the several parts of the Empire in scientific research and in the application of science to technical, biological, medical and economic problems.

The report now issued summarizes the discussions at the twelve meetings of the Committee. These discussions have been focused mainly on schemes for collecting and disseminating information, for $\theta x$ ample, on the model of the Imperial Agricultural Bureaux ; schemes for collaboration in research within the Empire; and schemes for facilitating visits and readier movement of research workers, university teachers and others within the Empire. The extension of such schemes to collaboration with the United States has also been discussed. The Committee has aimed at discovering, so far as possible, what is lacking in the existing machinery, and it stresses that the implications of the Atlantic Charter point inevitably 
to the need for closer political, social and technical collaboration with the United States, the U.S.S.R., China and other countries or regions. Planning collaboration in well-defined spheres of activity is a pressing need, first through the establishment of the best agreed co-operative machinery for exchange and dissemination of technical information and later by planning for co-operative research on problems common to all or to certain regions.

As an example of such a regional scheme, the report cites Brigadier B. F. J. Schonland's suggestion that institutes for research on African problems might be formed in such subjects as tropical diseases, social anthropology, native languages, ethnology, geology, geophysics and meteorology. Many important problems of world-wide significance are being investigated. independently in Empire countries and elsewhere, and the advantage which would result from co-operation between those countries willing to pool resources for the common good need scarcely be stressed. The Colonial Research Cớmmittee recently established under Lord Hailey's chairmanship should facilitate such co-operation, and the researches which may be undertaken by the Committee should also be coordinated with work in the Dominions and elsewhere.

It is unnecessary to reiterate here the examples cited in the report of fields in which such co-operation is called for and is related to programmes of post-war reconstruction, or to enumerate the various international organs already in existence, such as the International Locust Research Committee, the World Power Conference, and the International Institute of Agriculture. Proposals for the re-organization of some of these, for example, the International Health Organisation, were already under consideration at the outbreak of the War, and most of these services will need reviewing and probably revising in the most suitable form and on as wide an international basis as possible after the War. For the re-establishment of such co-operation Anglo-American initiative may indeed be essential, and further consideration will have to be given to machinery for close collaboration in research and the establishment of laboratories and institutes common to the Empire and the world.

On this question the report therefore makes three specific recommendations. First, that a suggestion be made to the Governments of the various Englishspeaking countries that they should consider the possibility of maintaining permanent scientific and technical representation in London and possibly also in other capital cities of the English-speaking world. Secondly, that such scientific and technical representatives of the Dominions and India permanently established in London should, together with official representatives of science in the United Kingdom and the Colonies, be constituted a British Commonwealth Scientific Collaboration Committee, to act with the Royal Society in the discussion of topics of common interest, to keep in touch with all agencies and organizations for the collection and dissemination of scientific information, to further schemes for cooperation in research, and to make such recommendations and proposals for common action as may seem fit. Thirdly, that if scientific and technical representatives of the United States and of other countries outside the British Commonwealth are established in London, arrangements should be made to seek their co-operation, so far as may be practicable and appropriate.

The wisdom of this last recommendation is so patent that the support of all scientific workers is assured. The report itself indicates that the New Zealand Council for Scientific and Industrial Research, the National Research Council of Canada and the National Research Board of South Africa are already prepared to support such collaboration. Scientific workers, however, should demonstrate emphatically their support both through their professional associations, and also in their private capacity as individual citizens, so that the Government can be in no doubt as to the extent of the support which is forthcoming for the proposal. There should be no ground for any pretence that the recommendations are in advance of what scientific workers as a body are prepared to endorse and wholeheartedly to implement.

The first of the six recommendations of the report, however, is one which makes even stronger demands for immediate support and response from scientific workers. There are, as the report points out, a number of bodies collecting and disseminating scientific information which might be assisted if made part of a wider scheme, and in particular, collaboration in the production of scientific abstracts of high quality for the common use of the English-speaking world would have the strong support of the Com. mittee. In accordance with this, the Committee recommends that the Royal Society should invite representatives of the appropriate scientific, technical and official bodies to meet as early as possible this year to discuss in general the further development of abstracting and information services as a co-operative effort between English-speaking countries, and, if agreed, to propose machinery for making a more detailed inquiry and for formulating more definite plans.

The report touches here on a demonstrable weak. ness in the organization of science. Besides the overlap between British Chemical and Physiological Abstracts and Chemical Abstracts and Science Abstracts, there are numerous examples of overlap and duplication in more limited fields, such as analy tical chemistry and particular industries, which are hard to defend to-day against the charge of extravagant use of labour and material. That this is now being more widely appreciated is indicated in an inquiry, sent out almost simultaneously with the publication of this report, to members of the Society of Dyers and Colourists, asking for an indication as to whether or not members would be prepared to dispense with the abstracts which are at present included in the Journal of that Society. Further opportunities for rationalization in a comprehensive scheme are clearly to be found in the abstracting services and publications of research associations and similar institutions, although here are to be found one or two examples of the effective elimination of duplicate effort. In the medical and biological sciences the position is much worse, and there are really wide opportunities of eliminating 
duplication of effort even within the limits of Great Britain.

There can be little doubt that rationalization in this field will be best secured under some comprehensive scheme covering all the sciences. Such a scheme will have the best chance of dealing with the difficulties in regard to nomenclature, bibliographic detail and the like which are apt to be a source of friction in smaller schemes when co-operation between allied sciences is involved. Moreover, under a large scheme, the savings to be achieved by genuine rationalization should make it unnecessary to continue some of the abbreviation practices to which some abstracting organizations have been forced in recent years owing to lack of resources. Such practices have been a minor source of irritation to many of the present users of such abstracts, and they offer a real obstacle to the wider use of the abstracts in their present form. Again, a central scheme is far better placed to encourage the use of new means for the rapid dissemination of information, such as microfilm, and to explore the possibilities of such developments.

The report shows that the Royal Society's committee is fully alive to the possibilities and to the need for rationalization of effort in the provision of an efficient and widespread information service. By extending, for example, to cover a wider field, the principle of the Imperial Agricultural Bureaux, which are maintained by a central organization, though working in separate institutes, greater financial stability, prevention of duplication and a closer coordination of the whole information service should be achieved. Rationalization of existing British organizations throughout the Empire should only be regarded as the first step. Scientific research and technical development have a fundamental bearing on economic factors, and the organization in each country for the collection and correlation of scientific information should be such that it would aid the collection of data by the economic bureaux.

The Committee is clearly right in holding that this whole issue must be the subject of detailed inquiry before any definite proposals are put forward. None the less, while such inquiry is proceeding, scientific workers could do much to prepare the way and to overcome the prejudices and other obstacles which have rendered abortive earlier and more limited efforts in this field. The growing complexity of science and technology, and the penetration of science into almost all human activities, make it essential that every effort should be made to provide as efficient an information service as possible; this is no longer a matter which concerns scientific workers alone.

If rapid progress can scarcely be looked for in the matter of this first recommendation, the situation is entirely different in regard to the last two recommendations of the report. There appears to be no good reason why immediate steps should not be taken to direct the attention of the Governments concerned and of independent agencies to the very great value of frequent and easy personal contacts and exchanges between research workers and students in various countries, which air transport should greatly facilitate in the future. For this purpose, largely increased funds would be required, and some plan for co-ordination would require working out with the various grant-giving bodies.

Similarly, there should be no delay in pointing out to the various Governments, universities and other authorities the advantages which would result from the institution of a system of sabbatical leave, to enable the scientific and technical staffs of academic, Government and industrial research organizations to make fuller use of such facilities as may, from time to time, be available for visits to other parts of the English-speaking world. In the whole of its remarks on this question of the flow of personnel, the report shows that the Committee is fully abreast of the most progressive thought in science and in industry. Here, as elsewhere, the report gives a clear lead to all scientific workers who wish to see science making a fuller contribution both to the war effort and to the task of post-war reconstruction. On them now rests the responsibility of seeing that that lead is followed, and that their existing organizations and societies do all that is possible to secure and support the necessary action required to implement the recommendations.

\section{IMPACT OF SOCIAL INFLUENCES UPON ART}

The Psychology of Cultural Change in Painting

By Dr. R. W. Pickford. (British Journal of Psychology, Monograph Supplements, 26.) Pp. vi+62. (Cambridge: At the University Press, 1943.) 8s. 6d. net.

TO painter can avoid some degree of seiff-expres1 sion; he may introduce a large amount of it, but in any event he is unlikely to be utterly objective. Whatever his choice of subject and treatment, his composition will be psychologically significant. What is perhaps even more important is that he has expended energy in the making of his picture and, through strife and toil, has arrived at something which, by highly complex paths, represents at last a function of his social environment. Thus, in the introduction to his monograph, Dr. R. W. Pickford paves the way for the detailed development of his theme. He is concerned neither with techniques nor with æsthetics; his task is to discuss social influences in their impact upon artists. In so doing, he performs a double service - to the man of science who realizes the profundity of all that is involved in creativeness (in whatever form), and to the historian, who is sometimes curiously reluctant to see in paintings the documents he most may need.

Naturally, this is scarcely a contribution for the layman. It is a closely woven pattern, cautious in the intertwining of warp and woof. However, one criticism the non-initiated might be tempted to make, and it may be worth while to anticipate it now. He would assert, in effect, that all this close analysis only amounts to what anybody with but a modicum of common sense would surmise in less time than that taken to say Jack Robinson. Examples are the effects upon leaders of those whom they lead, of frustration and of thwarted purpose, and so on. But in this he would be mistaken. A superficial interpretation of the nature of genius is usually rash, and 